\title{
Chapter 1: Background
}

\section{Introduction}

This study prepares a series of career ladders for the population of Oakland. Career ladders are long-term progression pathways to help individuals advance, particularly in high wage, high growth careers. Career ladders combine different statistics on the demographics of a population with statistics about the area's economic vitality and potential. This combination helps to identify the potential to strengthen an area's economy and enhance individuals' qualifications and wages.

One of the main reasons that people and large firms are attracted to a given city is the potential for economic stability. A stable economy is the result of the availability of jobs combined with the availability of a skilled labor force. When firms see the potential that a skilled labor force has, they are more eager to invest in the area with a venture that will provide jobs to the community while making a profit.

Oakland is unique in that about 42,000 people of the labor force can be identified as the "working poor." That is, they have jobs that do not pay enough to cover basic costs of living such as food and shelter. Approximately $62 \%$ of Oakland's population was in the labor force in the 2000 U.S. Census. Nearly $82 \%$ of neighboring Emeryville was in the labor force. While the numbers of people in either population are vastly different, Oakland reports about 150, 600 jobs compared to Emeryville's 19,800 jobs. In the last decade's recession, the City lost thousands of jobs, a phenomenon that makes the implementation of economic development strategies increasingly difficult. On the whole, the city of Oakland lags behind in economic development. As a whole, about $18 \%$ of Oakland's population has a Bachelor's degree, compared to about $28 \%$ of Emeryville. Combined with other factors, the difference in educational attainment in the neighboring cities attributes to the lower standard of living and higher rate of unemployment in Oakland compared to Emeryville. 


\section{Problem Statement}

These facts perpetuate a sequence of economic disinvestment in the area, causing large firms (and potential employers) to avoid starting and conducting business in Oakland. One essential way to reverse this cycle is to invest in the education and vocational training of the workforce. Since the unemployment rates all over the country are the highest they have been in decades, it is more important than ever to emphasize the importance of education and workforce development. There are proven strategies that cities can use to invest in workforce development and get their residents the jobs they need. Providing clearly defined and strategically developed career advancement paths will help jumpstart interest in Oakland's workforce investment programs.

The inter-related setbacks of the working poor in Oakland, California can be seen as having three stages or prongs: 1) The working poor are disadvantaged in their ability to afford to invest in their own education or vocational training, 2) High-wage firms do not see Oakland as a city with the high potential to hire good, well-educated workers, so they invest less time or effort in settling there than they normally would, 3) The working poor are disadvantaged in their efforts to get good-paying jobs that offer any benefits. This study sets out to help negotiate the barriers and obstacles that the working poor must face in order to advance their careers and lives.

\section{Definition of Poverty}

Before entering a discussion on the causes of poverty and possible solutions and approaches, a definition of the term is essential. Poverty is, in the most superficial sense, the inability to access core resources such as food, clothing and shelter. According to some researchers, "the essence of poverty is inequality. In slightly different words the basic meaning of poverty is relative deprivation" (Valentine, 1968). A more technical definition comes from the U.S. Department of Agriculture: the poverty line. The poverty line is a statistical measure of poverty developed in 1963 to define the amount of money that should be spent on an adequate diet. Regardless of which definition is appropriate for a given situation, it is important to remember that the act of defining poverty is inherently political. "Which view of poverty 
we ultimately embrace will have a direct bearing on the public policies we pursue" (Schiller, 1989). The reason why it is compulsory to define poverty is that the resulting knowledge we gain will shape the futures of the working poor in Oakland.

\section{Theories of Poverty}

The question of why there are poor people in Oakland gleans several answers and theories, each of which may be correct depending on circumstance. The belief that the poor are poor because they are lazy and/or irresponsible has been a long-held and popular belief among certain schools of thought. As early as the 1960s, their situation could be easily postulated: "By the time slum children are age six or seven they have usually absorbed the basic values and attitudes of their subculture and are not psychologically geared to take full advantage of changing conditions or increased opportunities which may occur in their lifetime" (Lewis, 1966). Even early religious doctrine equated prosperity with being in God's favor (Weber, 2001). However, recent research indicates several different theories about the causes of poverty. Most researchers and authors take one side of the controversy over the cause of poverty: They either believe that poverty is the individual's own fault or that poverty is the result of the way our system is set in place. That is, some researchers have come to the conclusion that poverty stems from the systemic discrimination of underrepresented societal groups. These two views often clash; efforts to respond to poverty seem to clash depending on the paradigm under which any given community development corporation (CDC) operates.

\section{Poverty Caused by Individual Deficiency}

Theories emphasizing the individual's work ethic state that poverty is caused by individual laziness, incompetence, and bad choices. These theories stem from neoclassical economic theory, which emphasizes the role of personal traits, such as family background and education level, in affecting people's economic well-being (Iceland, 2006). Because the U.S. operates on a paradigm of competition, this means that winners are rewarded and those who do not work hard or make bad choices are punished for their actions. This seems to be the most popular belief in the U.S. today: poverty is presumed to follow from an unwillingness to enter the labor force (Newman, 1999). Potential responses by local and 
regional CDCs operating under this paradigm include countering efforts to individualize poverty and offering assistance to families (Bradshaw, 2005). These efforts become a sort of safety net for families who find themselves in poverty. Examples of these efforts include drug rehabilitation programs, the Food Stamps Program and the Women, Infants, and Children (WIC) Program.

\section{Poverty Caused by Economic, Political, and Social Distortions or Discrimination}

Other theories account for the impact that various social, economic, and political systems have on poverty. These theories state that systemic barriers exist that prevent the poor from access and accomplishment in key social institutions including jobs, education, housing, health care, safety, political representation, etc." (Bradshaw, 2005). For example, economic growth determines absolute increases and decreases in average standards of living. Similarly, economic inequality affects the distribution of income (Iceland, 2006). CDC responses that parallel this paradigm would seek to gain political and economic power or create alternative organizations to achieve change (Bradshaw, 2005).

\section{Study Purpose}

Though it is clear that investment in human resources is pivotal to economic development, research shows that $90 \%$ of U.S. workers need to improve their computer skills and $60 \%$ need to improve their analytical skills in order to keep doing their current jobs (The Board of Governors of the California Community Colleges, 2001). In this dynamic economy, it is more important than ever that the labor force of Oakland get the education and training they need to make significant contributions to society. Not only will the people benefit from higher education, better jobs, higher wages, and better benefits, but the City of Oakland will benefit from a labor force that is attractive to large firms and companies. Though the issues that the working poor face are great, it is clear that some of the poverty in Oakland is preventable and some of the obstacles that some must cope with are not necessary. This study sets out to assist in negotiating those barriers.

There have been several strategies for workforce development all over the world and at different governmental levels. Some of these strategies have nothing at all to do with the public sector; some private firms and companies have their own development curricula that emphasize leadership and 
management skills. Three strategies for workforce development follow this introduction. They include the One-Stop Career Centers System, the Alliance of Skills Sector Councils in the U.K. and the Career Ladders Project in California.

\section{One Stop Career Centers}

The One-Stop Career Centers System is a system of physical and electronic sites where comprehensive services to job seekers are available (Wilson, 1995). The program was started in response to changing paradigms and work patterns in the California labor force. One-Stop Career Centers offer a variety of services, including assessment and eligibility, referral and job coaching/workshops, education and training, job search/ labor market information, and job placement and follow-up (Wilson, 1995).

Critiques of this system include the requirement of an individual to be very proactive in seeking out the centers on his/her own. They are not typically well connected to community development organizations where people may come together for resources relevant to their own experiences. In addition, One-Stop Career Centers are not sector-based. That is, they will match up an individual with any job that is appropriate to their skills, whether or not that job has any potential to advance the individual's career.

\section{Alliance of Sector Skills Councils}

The Alliance of Sector Skills Councils is a system of organizations in the U.K. that are industryled and owned and operated by employers. The aim of the Sector Skills Councils (SSCs) is to ensure a more productive and competitive workforce in the U.K. The SSCs focus on achieving economic impact, being at the forefront of skills and the employment system, working effectively with partners and collectively delivering standards, qualifications and producing labor market intelligence (Alliance of Sector Skills Councils, 2010).

\section{The California Career Ladders Project}

The Board of Governors of California's community colleges has established that there is a significant need in California to develop a strategy for workforce development that is universal, seamless 
and founded on career ladders. Career ladders help cultivate skills in individuals to help them succeed in a changing workplace. They are "long-term career progression pathways to help individuals advance, particularly in high wage, high growth careers" (The Board of Governors of the California Community Colleges, 2001). This strategy for economic development stems from the ever-changing demands of the work environment. It used to be that general skills and little education could get you a decent job that paid decent wages. Today, there are advanced skills necessary for workplace survival that can only be obtained through education and vocational training. The Career Ladders Project offers industry-specific vocational training and career counseling, a benefit not offered by the One-Stop Career Center System. Career ladders help to maintain an employee's skill set and advance them through higher positions and wages. California's community colleges have been making the effort to partner up with employers and employment training agencies to build the capacity of the California workforce.

The best of these three strategies have much to offer the City and residents of Oakland. The people of Oakland need specific places to go for career counseling and job referrals, such as a Career Center offered through the One-Stop system. It is centers like these that are so highly taken advantage of throughout the City. The people also need industry-specific vocational training in industries that have the potential for career advancement, like that offered by the A.S.S.C. in Europe and the Career Ladder Project here in California. 


\section{Chapter 2: Methodology}

This study first required both Internet and library research of different strategies for workforce development. Then, demographic comparisons were made for the City of Oakland. The majority of the research for this project utilized Census 2000 data, the most recent accurate data available at the neighborhood level. While the areas where people earn the lowest incomes have not changed significantly, the recessions of the last decade as well as the brief Internet recession around the year 2000 have the potential to change some estimates and projections. This information was obtained from the U.S. Census 2000 Summary Files as well as Census information by map. Educational attainment data was also obtained from the 2000 U.S. Census and organized into graphs to better visualize the educational conditions in Oakland. Economic data for Oakland was obtained and reorganized from the 2002 and 2007 U.S. Economic Censuses. Jobs and housing data were obtained from the U.S. Census Bureau Longitudinal Employer Dynamics, using OnTheMap technology to map locations of jobs held by Oakland residents. Finally, employment trends and projections were obtained from the Bureau of Labor Statistics.

All of this information was then evaluated to identify deficiencies in the provision of personnel, potential growth areas and training needs. The results of this study are applied in the development of career ladders for the City of Oakland. 


\section{Chapter 3: Demographics Comparisons-Citywide}

A description of these statistics will provide a more accurate picture of the population of Oakland and can inform policy decisions and help determine the future need of services in the area. For the purposes of this study, demographics in Oakland include information on race, age, sex, educational attainment, income, and poverty levels.

\section{Educational Attainment}

Educational attainment in Oakland shows some variance by race. See Table 3-1 and 3-2 for numbers and percentages and Figure 3-1. The white population has the highest number and percentage of the population who have attained a graduate degree or above. The black or African American population has the highest number and percentage of people who have attained between a high school diploma and an Associate degree. Nearly half of the entire American Indian or Alaskan Native population in Oakland has attained between a high school diploma and an Associate degree. The Asian population has the most even distributed educational attainment. The Native Hawaiian and Pacific Islander population also has nearly half of their population in the mid-range of educational attainment. Finally, more than half of Oakland's Hispanic population has attained less than a high school diploma.

The low educational attainment in the Hispanic population may be attributed to the degree that the population is migratory. The seasonal labor of farm work requires that people and their families are constantly uprooted to begin a new chapter of life in a new place. Constant movement to different geographic locations is not conducive to a steady education. On the other hand, the racial groups that may be more settled in one area seem to have attained higher education. For example, the white and black or African American populations have relatively higher levels of educational attainment than the other racial groups. However, the history of racial discrimination in housing as well as gentrification has also displaced many other people of color, making access to a steady education a challenge. 
Table 3-1: Educational Attainment by Race for Oakland, CA

\begin{tabular}{|c|c|c|c|c|c|c|c|}
\hline $\begin{array}{c}\text { Educational } \\
\text { Attainment }\end{array}$ & All & White & Black & Am. Indian & Asian & Hawaiian & Hispanic \\
\hline Less than HS & 68,419 & 13,747 & 20,018 & 537 & 16,312 & 410 & 26,176 \\
\hline HS - Assoc. & 137,901 & 32,386 & 54,616 & 826 & 14,684 & 584 & 14,016 \\
\hline Grad + & 83,686 & 51,872 & 14,797 & 257 & 11,400 & 140 & 4,698 \\
\hline Total & 290,006 & 98,005 & 89,431 & 1,620 & 42,396 & 1,134 & 44,890 \\
\hline
\end{tabular}

Source: Census 2000 Summary File (SF3) P148A, B, C, D, E, H. Oakland city, California.

Table 3-2: Percentage of Educational Attainment by Race for Oakland, CA

\begin{tabular}{|c|c|c|c|c|c|c|c|}
\hline $\begin{array}{c}\text { Educational } \\
\text { Attainment }\end{array}$ & All & White & Black & Am. Indian & Asian & Hawaiian & Hispanic \\
\hline Less than HS & $24 \%$ & $14 \%$ & $22 \%$ & $33 \%$ & $38 \%$ & $36 \%$ & $58 \%$ \\
\hline HS - Assoc. & $48 \%$ & $33 \%$ & $61 \%$ & $51 \%$ & $35 \%$ & $51 \%$ & $31 \%$ \\
\hline Grad + & $29 \%$ & $53 \%$ & $17 \%$ & $16 \%$ & $27 \%$ & $12 \%$ & $10 \%$ \\
\hline Total & $100 \%$ & $100 \%$ & $100 \%$ & $100 \%$ & $100 \%$ & $100 \%$ & $100 \%$ \\
\hline
\end{tabular}

Source: Census 2000 Summary File (SF3) P148A, B, C, D, E, H. Oakland city, California.

Figure 3-1: Educational Attainment by Race in Oakland, CA

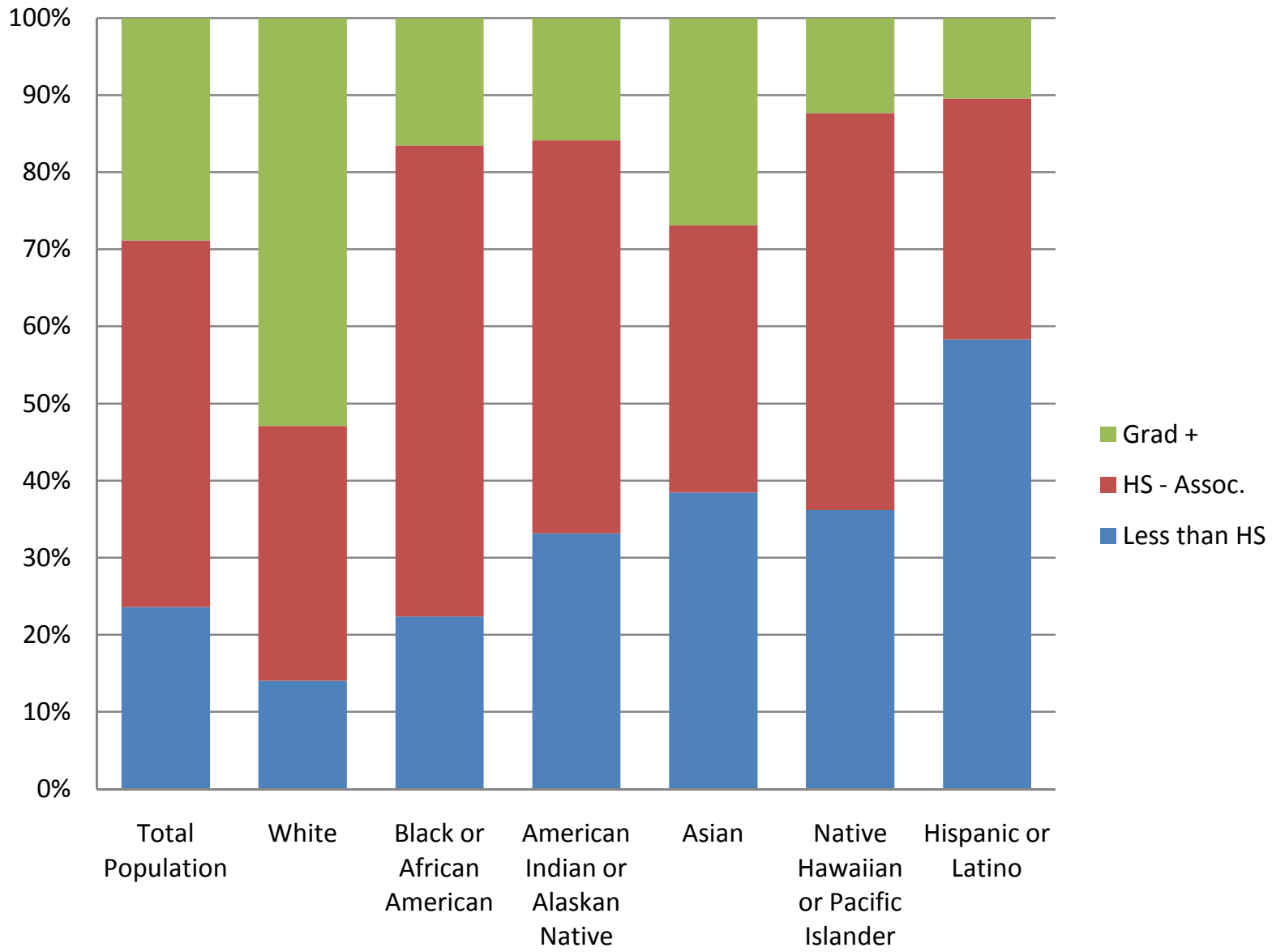

Source: Census 2000 Summary File (SF3) P148A, B, C, D, E, H. Oakland city, California. 


\section{Income Distribution}

Figure 3-2 shows the disparity in household incomes for the population of Oakland. The graph shows that about ten percent of the population earns nearly 30 percent of the income in Oakland. If income distribution in Oakland was even and equal by race, the other income trends by race would follow the straight line dividing the graph in two. While the variance by race is not extreme, the most disparity occurs between Native Hawaiian or Other Pacific Islanders and the Asian population. In general, the Lorenz curve indicates a 44\%-48\% deviation from equality in the distribution of incomes by race which, although not unique to Oakland, is worth noting because it depicts the disparity in income distribution by race.

Figure 3-2: Household Income in 1999 by Race in Oakland, CA

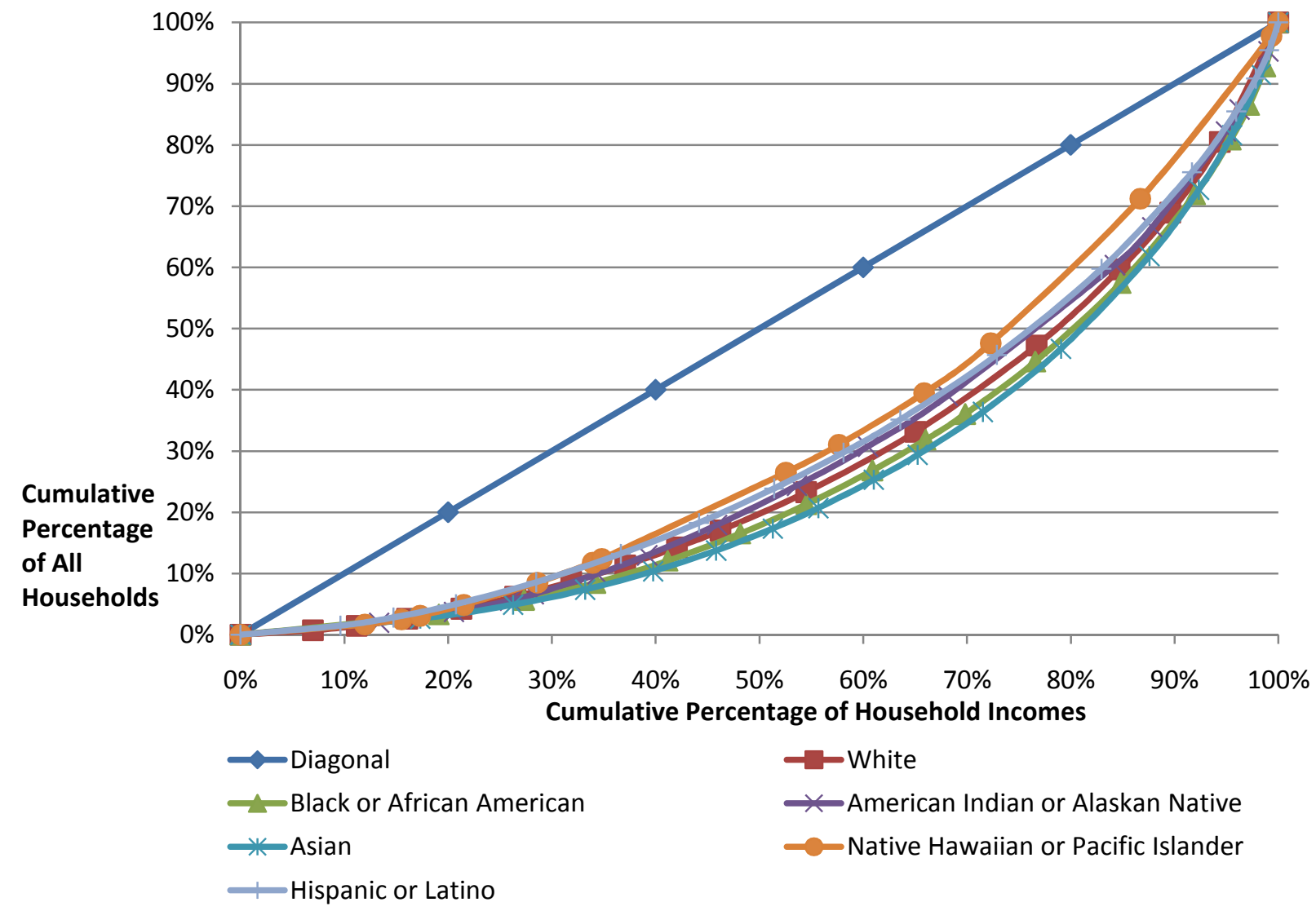

Source: Census 2000 Summary File (SF3) P151A, B, C, D, E, H. Oakland city, California.The Spatial Distribution of Demographic Characteristics 


\section{Concentrations of Low Educational Attainment and Incomes}

The following four maps are a visual representation of different (but related) demographic statistics regarding the population of Oakland. The first, Figure 3-3, shows the percentage of the population who have less than a $9^{\text {th }}$ grade level of education. This population seems to reside in higher concentrations near the western side of the city and closer to the U.S. I-880 Freeway and the bay. The next map shows the percentage of the population who were earning an income of less than $\$ 10,000$ per year. Again, the majority of people living in poverty live closer to the western side of the city and the bay and also seem to line the freeway. Figure 3-5 shows the percentage of the population of Oakland that is employed in the low-paying manufacturing industry. Figure 3-6 shows a similar distribution for those employed in the construction and extraction industry. These four maps together reveal the cycle of poverty in Oakland: low educational attainment means that people cannot get high paying jobs and must settle for low-paying, low-skill occupations. Though there are many factors that dictate whether a firm locates in an area (such as land prices), higher paying industries in promising industries may not cluster in an area where there is a lack of investment in education and deep geographical disparities in educational attainment. 
Figure 3-3: Percent of Population 25 Years or Older with Less Than a $9^{\text {th }}$ Grade Education: 2000

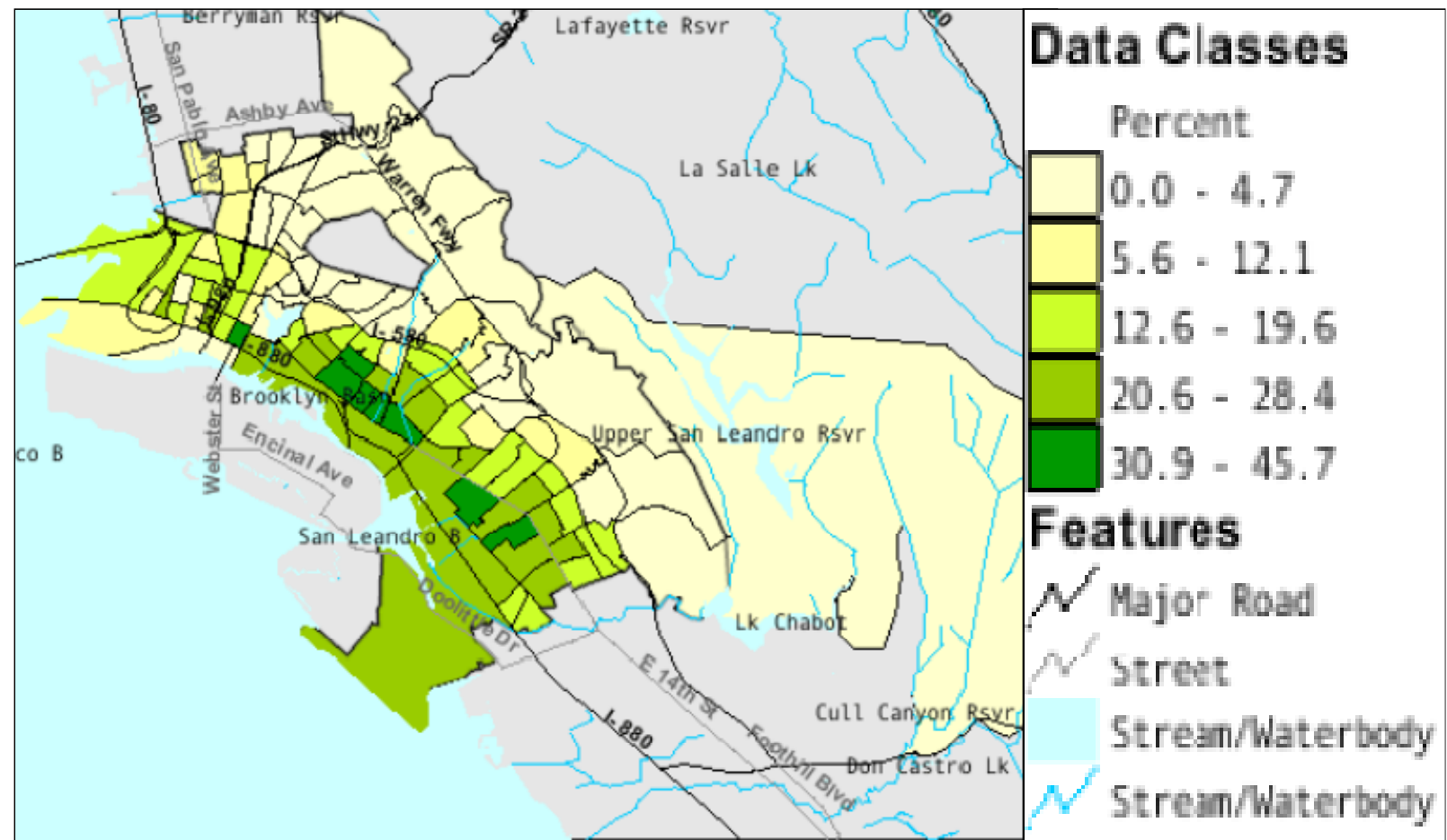

Source: Census 2000 Summary File 3 (SF 3) - Sample Data TM-P040

Oakland city, California by Census Tract

Figure 3-4: Percent of Households with Income Less than \$10,000 in 1999: 2000

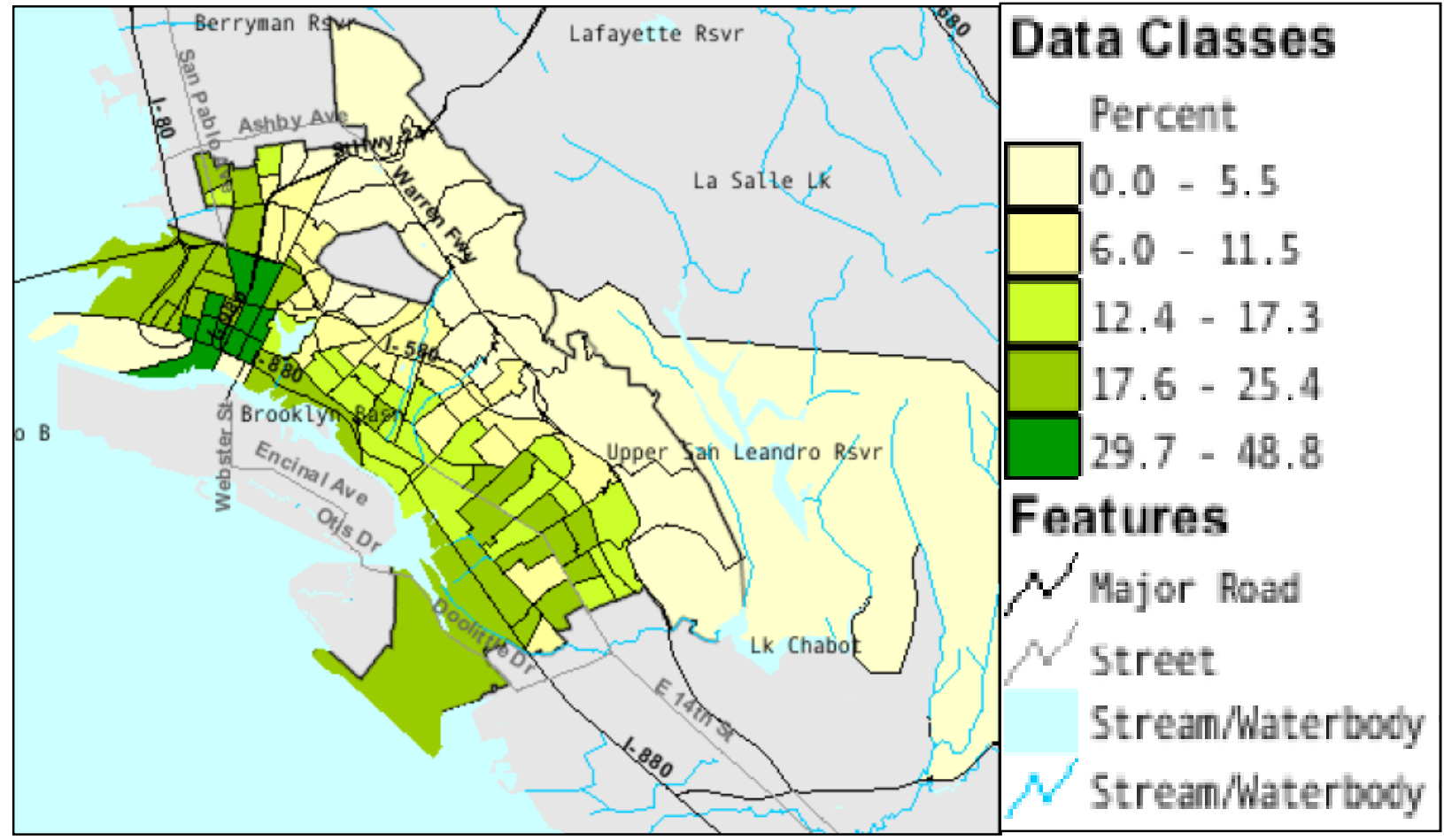

Source: Census 2000 Summary File 3 (SF 3) - Sample Data TM-P061

Oakland city, California by Census Tract 
Figure 3-5: Percent of Employed Civilian Persons 16 Years and Over in Manufacturing Industries: 2000

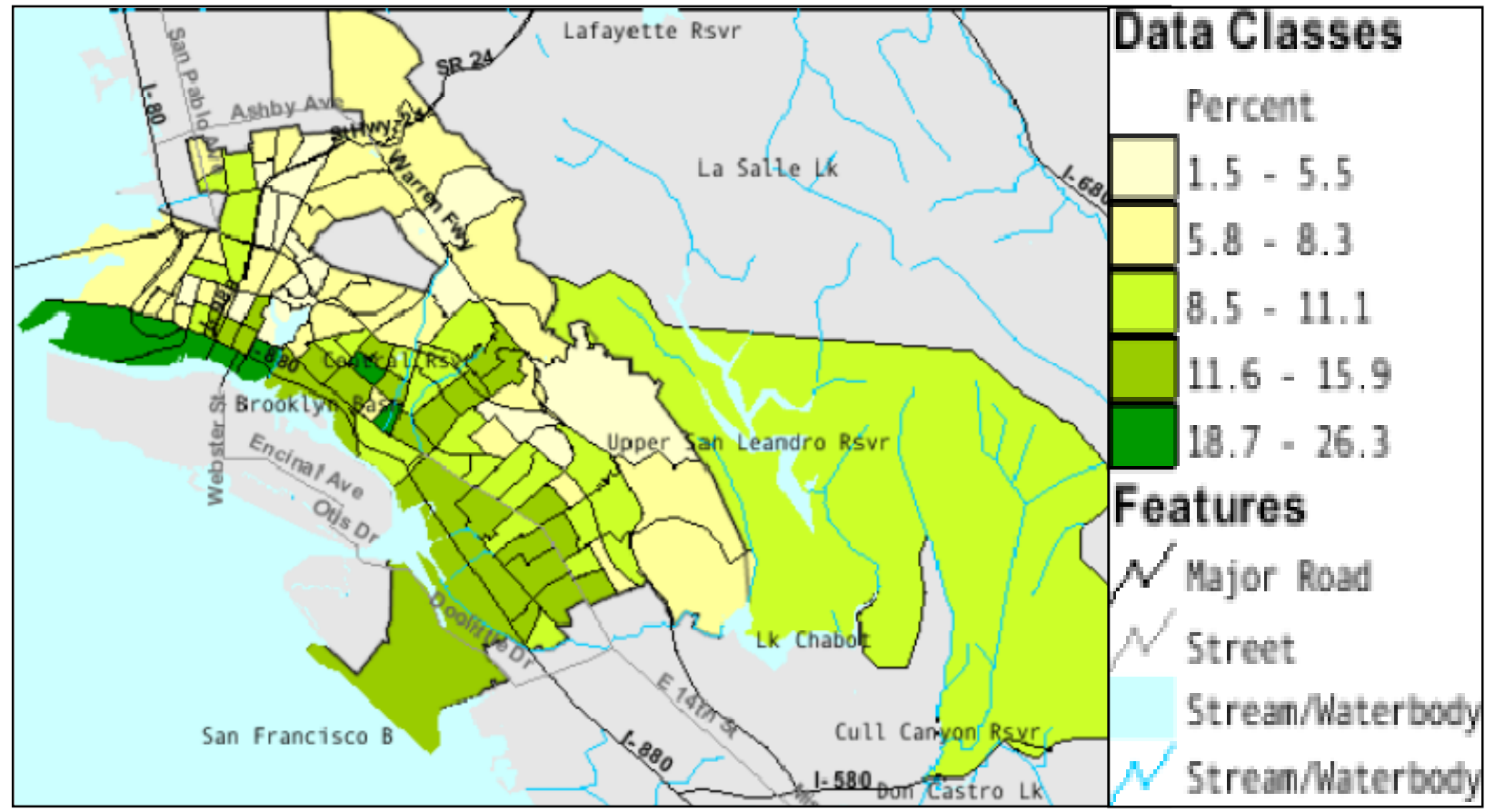

Source: Census 2000 Summary File 3 (SF 3) - Sample Data TM-P052

Oakland city, California by Census Tract

Figure 3-6: Percent of Employed Civilian Persons 16 Years and Over in Construction, Extraction, and Maintenance Occupations: 2000

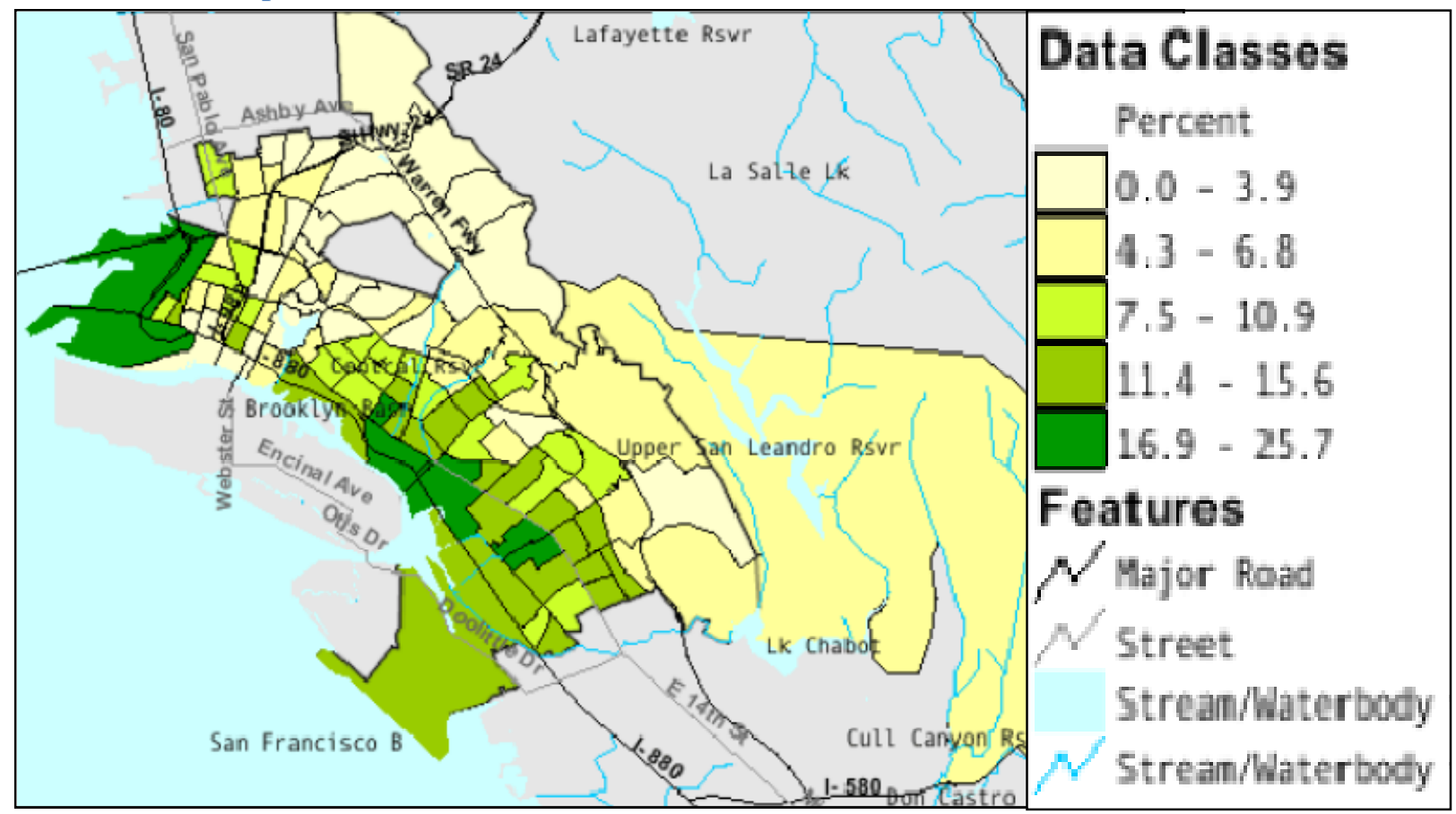

Source: Census 2000 Summary File 3 (SF 3) - Sample Data TM-P057

Oakland city, California by Census Tract 


\section{Concentrations of High Educational Attainment and Incomes}

The following four maps show the relationship between increased educational attainment, increased income, and high-paying jobs. The first two maps show the higher levels of educational attainment. That is, the percent of people who have attained higher than a high school diploma and the percent of people who have earned a Bachelor's degree or higher. These are held mostly by residents of the eastern side of the city and up into the hills. Figure 3-9 shows the percentage of the population that earned $\$ 100,000$ or more in 1999 , which is very similar to the previous two maps. Finally, Figure 3-10 shows the percentage of people employed in management and other related occupations. These occupations generally offer a higher wage than other occupations, which may explain the prevalence of them in the same areas where people have higher educational attainment levels.

Figure 3-7: Percent of Persons 25 Years and Over with High School Diploma or More Education: 2000

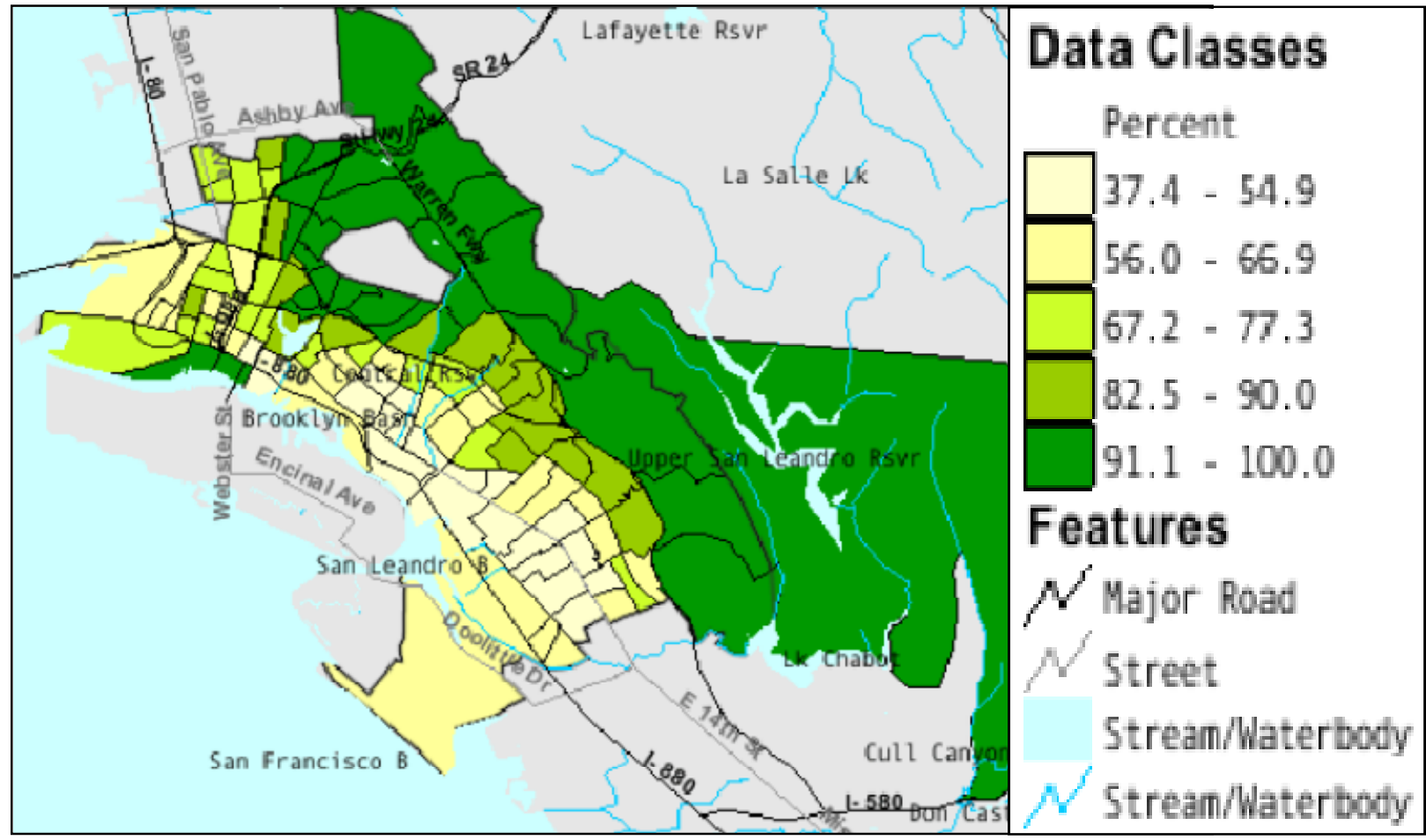

Source: Census 2000 Summary File 3 (SF 3) - Sample Data TM-P041 Oakland city, California by Census Tract 
Figure 3-8: Percent of Persons 25 Years and Over with Bachelor's Degree or Higher: 2000

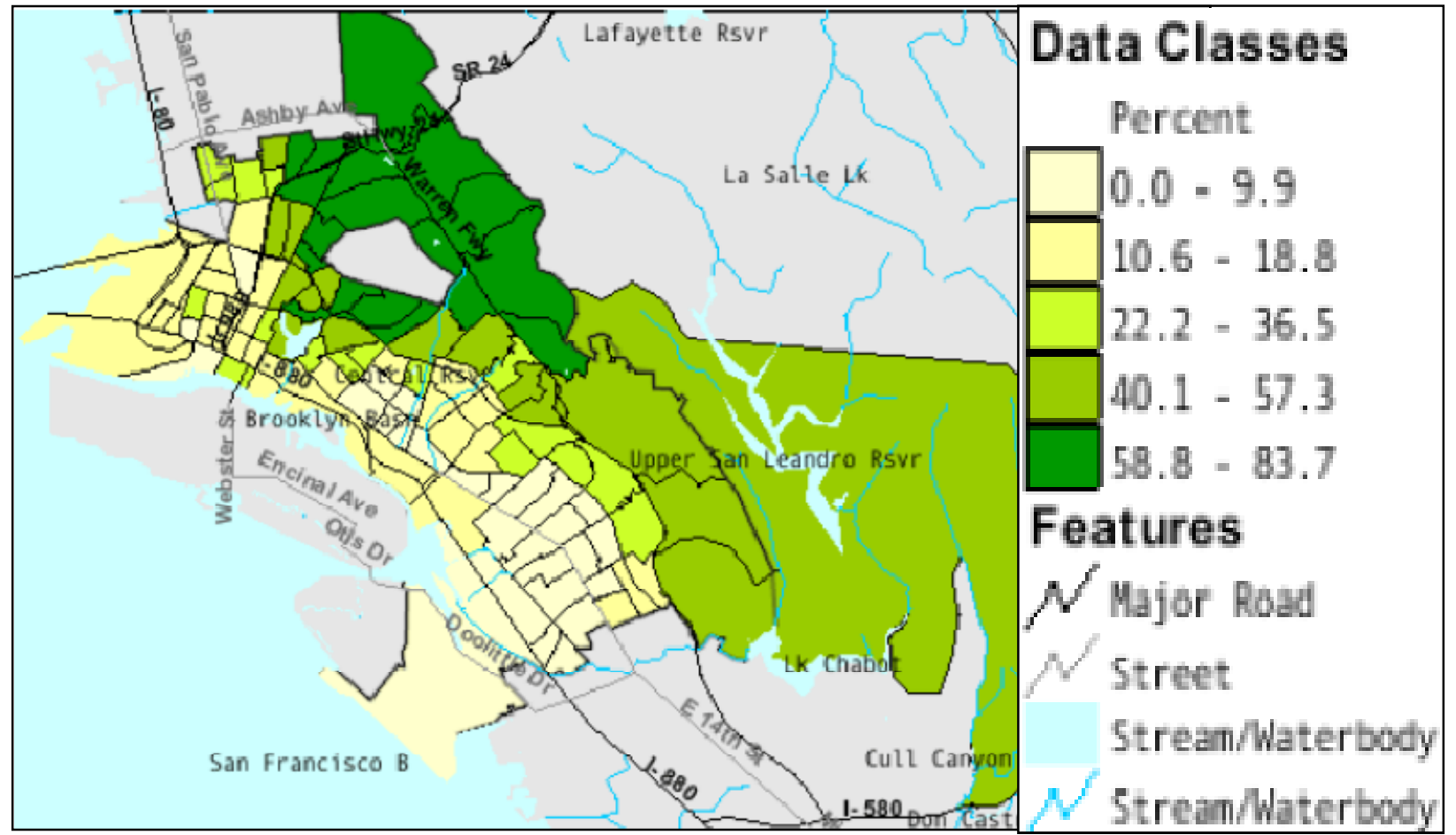

Source: Census 2000 Summary File 3 (SF 3) - Sample Data TM-P042

Oakland city, California by Census Tract

Figure 3-9: Percent of Households with Income of \$100,000 or More in 1999: 2000

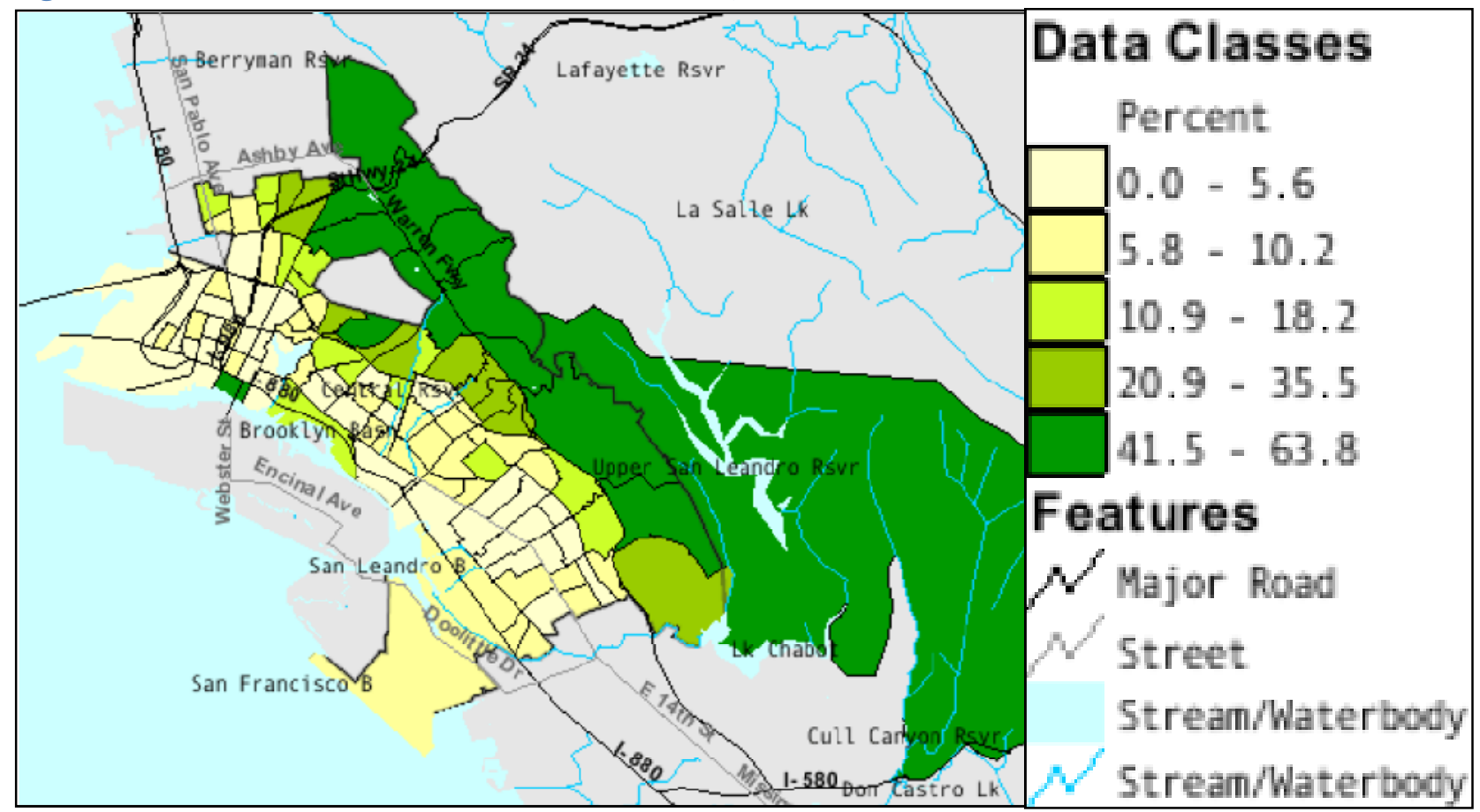

Data Set: Census 2000 Summary File 3 (SF 3) - Sample Data TM-P062

Oakland city, California by Census Tract 
Figure 3-10: Percent of Employed Civilian Persons 16 Years and Over in Management, Professional, and Related Occupations: 2000

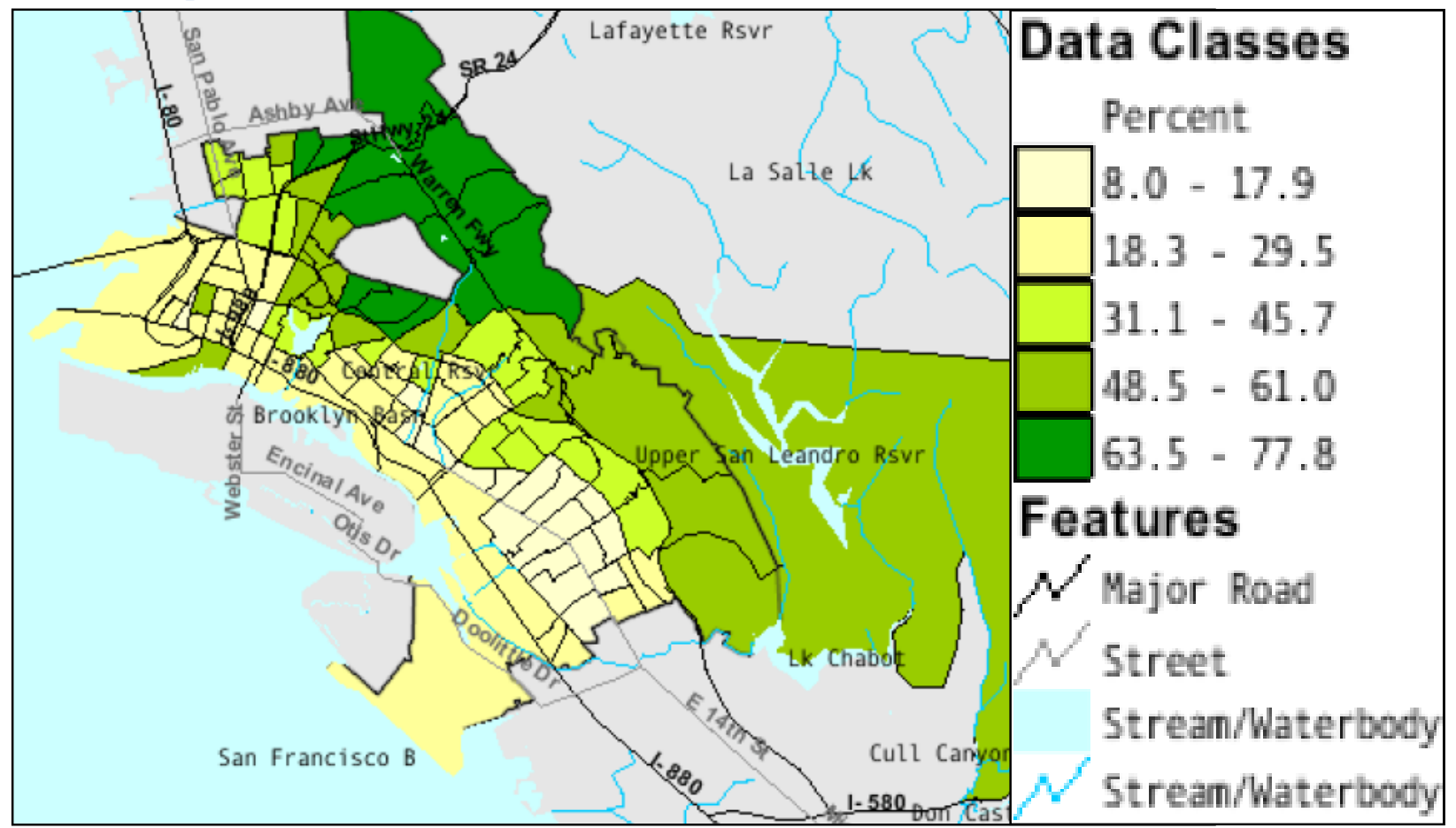

Source: Census 2000 Summary File 3 (SF 3) - Sample Data TM-P053

Oakland city, California by Census Tract

A review of the demographics and socioeconomics of Oakland reveals that there are major correlations between income, educational attainment, and wages. In Oakland, the population is geographically distributed by income class. Those with lower educational attainment, engage in lower paying jobs, and have lower incomes reside mainly on the west. Those with higher educational attainment, engage in higher paying jobs, and have higher incomes reside mainly on the east side. In addition, educational attainment is unequal across racial groups and is higher in some neighborhoods than in others. Therefore, this study will seek to improve conditions for those disadvantaged groups on the West side of Oakland through the creation of career ladders.

\section{Distribution of Labor Force by Industry}

Figure 3-11 shows that, while there is a fairly even distribution of employees by industry in Oakland, one industry, Health Care and Social Assistance, stands apart from the rest in number of persons employed in 2000. Tables 3-3 and 3-4 show that the average wage earned by an individual is very 
dependent on the industry in which one is employed. These two tables compare trends in wage and employment over time (between 2002 and 2007). Because the wages and employment numbers are similar over time, the trends in data are stable and still applicable to the creation of career ladders. According to these tables, the four lowest paying industries in Oakland are:

- Accommodation and food services

- Educational services

- $\quad$ Retail trade

- Administrative and Support and Waste Management

The 2000 Census shows that the median income in Oakland was $\$ 40,055$. According to the standard definition of income categories, those who earn below 80 percent of the Area Median Income (AMI) are considered low income. This means that in Oakland, those who earn below $\$ 32,044$ will be considered low income households. The four identified industries pay wages that are lower than the low-income threshold of $\$ 30,000$ per year. Table 3-3 also shows that these four industries also made up one third of those employed in 2002 as well as 2007 . The efforts of the career ladders will seek to improve the economic opportunities for this population by providing a guide to better educational attainment and, therefore, higher-paying jobs. 
Figure 3-11: Number of Employees in Oakland by Industry in 2007
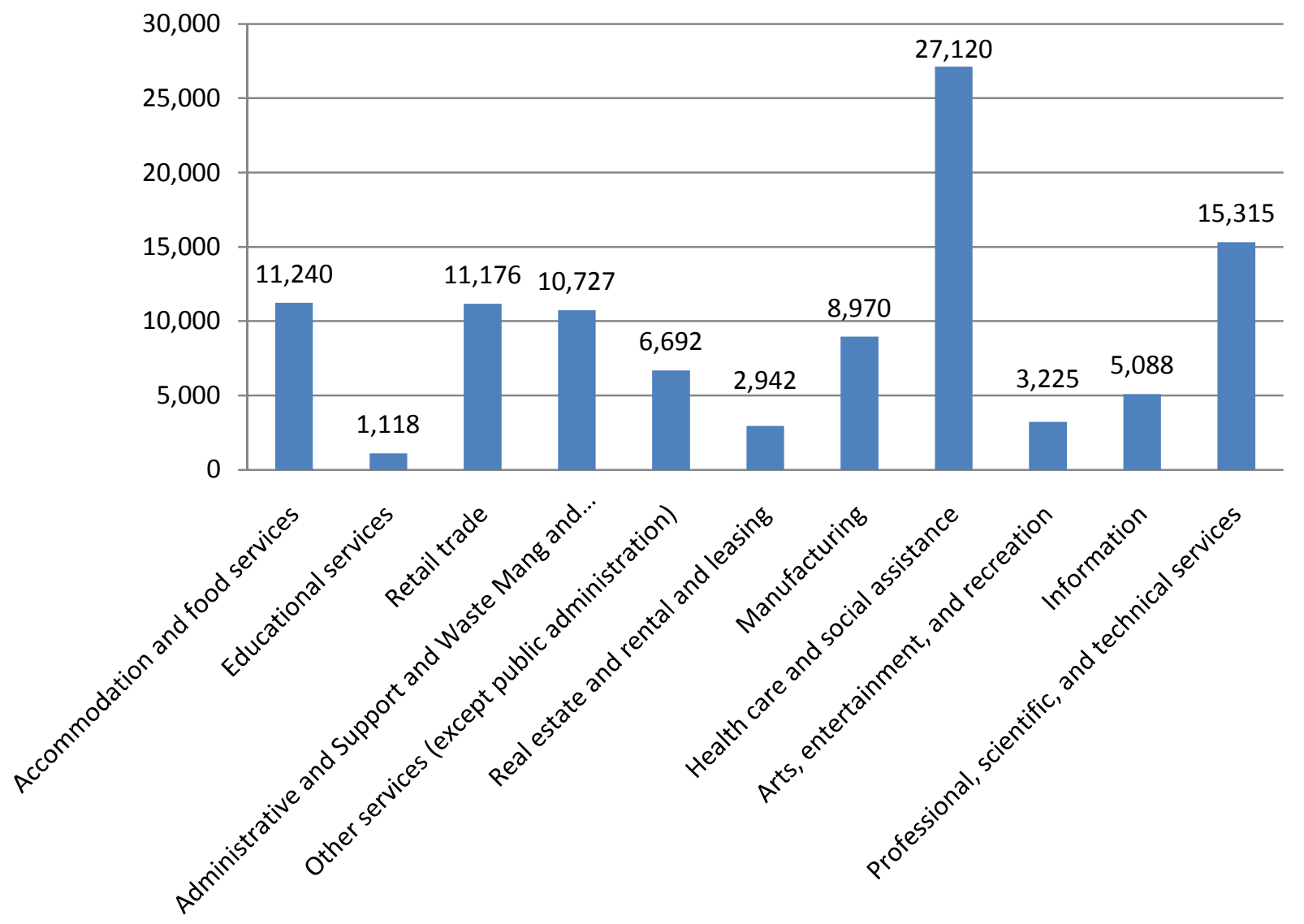

Source: Economic Census 2007 Table 1: Selected Statistics by Economic Sector: 2007 Oakland city, CA 
Table 3-3: Distribution of Oakland Employees by Industry and Annual Wage in 2002

\begin{tabular}{|l|c|c|c|c|}
\hline \multicolumn{1}{|c|}{ Industry description } & $\begin{array}{c}\text { Average Annual } \\
\text { Wage (Nominal } \\
\text { Dollars) }\end{array}$ & $\begin{array}{c}\text { Number of } \\
\text { employees }\end{array}$ & $\begin{array}{c}\text { Percent of } \\
\text { Employees }\end{array}$ & $\begin{array}{c}\text { Cumulative Percent } \\
\text { of Employees }\end{array}$ \\
\hline $\begin{array}{l}\text { Accommodation \& food } \\
\text { services }\end{array}$ & $\$ 15,608.22$ & 10,335 & $9 \%$ & $9 \%$ \\
\hline $\begin{array}{l}\text { Administrative \& support \& } \\
\text { waste management \& } \\
\text { remediation service }\end{array}$ & $\$ 25,438.95$ & 11,195 & $10 \%$ & $19 \%$ \\
\hline Retail trade & $\$ 28,251.60$ & 1,248 & $1 \%$ & $29 \%$ \\
\hline Educational services & $\$ 28,663.12$ & 6,581 & $6 \%$ & $30 \%$ \\
\hline $\begin{array}{l}\text { Other services (except public } \\
\text { administration) }\end{array}$ & $\$ 31,588.52$ & 2,875 & $3 \%$ & $36 \%$ \\
\hline Real estate \& rental \& leasing & $\$ 37,917.22$ & 11,065 & $10 \%$ & $39 \%$ \\
\hline Manufacturing & $\$ 44,357.13$ & 25,708 & $23 \%$ & $49 \%$ \\
\hline Health care \& social assistance & $\$ 45,956.84$ & 7,460 & $7 \%$ & $79 \%$ \\
\hline Wholesale trade & $\$ 50,655.38$ & 5,847 & $5 \%$ & $84 \%$ \\
\hline Information & $\$ 63,899.65$ & 14,988 & $14 \%$ & $98 \%$ \\
\hline $\begin{array}{l}\text { Professional, scientific, \& } \\
\text { technical services }\end{array}$ & $\$ 70,559.65$ & 2,196 & $2 \%$ & $100 \%$ \\
\hline $\begin{array}{l}\text { Arts, entertainment, \& } \\
\text { recreation }\end{array}$ & - & 110,753 & $100 \%$ & - \\
\hline Total & $\$ 255$ & $10 \%$ & \\
\hline
\end{tabular}

Source: Economic Census 2002 Table 1: Selected Statistics by Economic Sector: 2002 Oakland city, California 
Table 3-4: Distribution of Oakland Employees by Industry and Annual Wage in 2007

\begin{tabular}{|c|c|c|c|c|}
\hline Industry description & $\begin{array}{l}\text { Average Annual } \\
\text { Wage (Nominal } \\
\text { Dollars) }\end{array}$ & $\begin{array}{l}\text { Number of } \\
\text { Employees }\end{array}$ & $\begin{array}{l}\text { Percent of } \\
\text { Employees }\end{array}$ & $\begin{array}{c}\text { Cumulative Percent } \\
\text { of Employees }\end{array}$ \\
\hline $\begin{array}{l}\text { Accommodation and food } \\
\text { services }\end{array}$ & $\$ 17,803$ & 11,240 & $11 \%$ & $11 \%$ \\
\hline Educational services & $\$ 23,343$ & 1,118 & $1 \%$ & $12 \%$ \\
\hline Retail trade & $\$ 28,095$ & 11,176 & $11 \%$ & $23 \%$ \\
\hline $\begin{array}{l}\text { Administrative and Support } \\
\text { and Waste Mgmt and } \\
\text { Remediation Srvs }\end{array}$ & $\$ 29,137$ & 10,727 & $10 \%$ & $33 \%$ \\
\hline $\begin{array}{l}\text { Other services (except public } \\
\text { administration) }\end{array}$ & $\$ 32,528$ & 6,692 & $6 \%$ & $40 \%$ \\
\hline $\begin{array}{l}\text { Real estate and rental and } \\
\text { leasing }\end{array}$ & $\$ 38,073$ & 2,942 & $3 \%$ & $42 \%$ \\
\hline Manufacturing & $\$ 43,145$ & 8,970 & $9 \%$ & $51 \%$ \\
\hline $\begin{array}{l}\text { Health care and social } \\
\text { assistance }\end{array}$ & $\$ 59,715$ & 27,120 & $26 \%$ & $77 \%$ \\
\hline $\begin{array}{l}\text { Arts, entertainment, and } \\
\text { recreation }\end{array}$ & $\$ 71,551$ & 3,225 & $3 \%$ & $80 \%$ \\
\hline Information & $\$ 72,456$ & 5,088 & $5 \%$ & $85 \%$ \\
\hline $\begin{array}{l}\text { Professional, scientific, and } \\
\text { technical services }\end{array}$ & $\$ 74,826$ & 15,315 & $15 \%$ & $100 \%$ \\
\hline Total & - & 103,613 & $100 \%$ & - \\
\hline
\end{tabular}

Source: Economic Census 2007 Table 1: Selected Statistics by Economic Sector: 2007 Oakland city, California 
Figure 3-12: Average Annual Wage for Oakland Industries

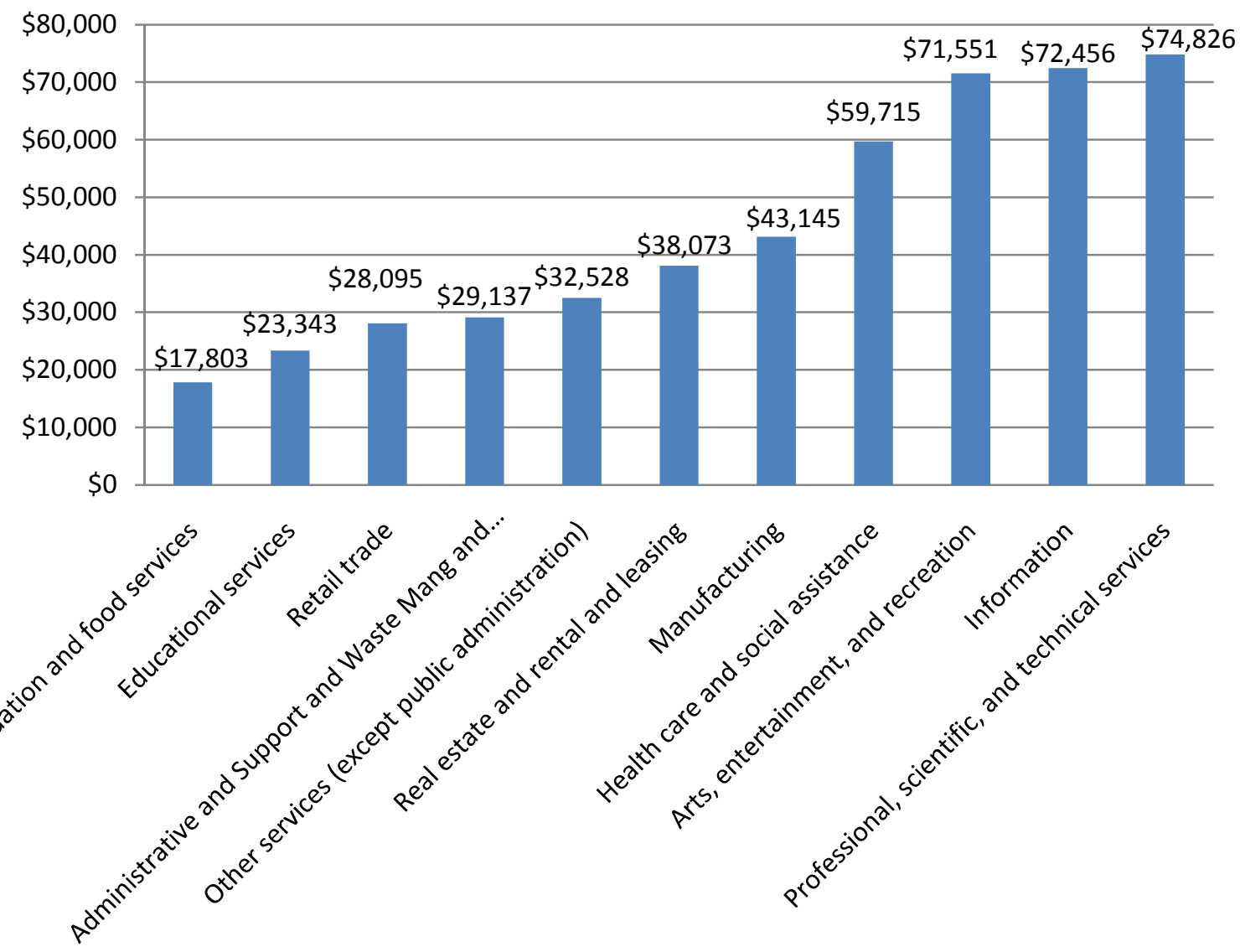

Source: Economic Census 2007 Table 1: Selected Statistics by Economic Sector: 2007 Oakland city, California

\section{Future Population and Labor Force}

Projections and estimates for statistics such as population and employment help to assess future needs of a given community. Such estimates offer a possible depiction of future conditions so that a community can better adapt its efforts to offer better services to the people. For the purposes of this study, the targets are people with low educational attainment.

Population projections show that the Oakland population is steadily increasing. If the distribution of employment opportunities stays the same while the population continues to increase, then the number of economically disadvantaged people will also increase. It is this number of people that this study aims to serve by improving opportunities for those who could remain disadvantaged. 
See Tables 3-5 through 3-7 for numbers and percentages. According to the U.S. Census

Bureau Longitudinal Employer-Household Dynamics (LEHD), there were approximately 169,000 jobs in Oakland in 2007. Of that number, about 25 percent of employees (or 42,700 people) lived in Oakland in addition to working there. Some of these people can potentially benefit from the findings of this study. According to calculated population estimates for Oakland in the year 2020, that number could jump to nearly 75,000 employees who also live in Oakland and may have some interest in the findings of this study. As the Oakland population increases, the number of economically disadvantaged employees could easily increase if current conditions stay the same over time.

Table 3-5: Number of Jobs in Oakland in 2007

\begin{tabular}{|l|c|c|c|c|}
\hline & \multicolumn{2}{|c|}{2007} & \multicolumn{2}{|c|}{2002} \\
\hline & Count & Share & Count & Share \\
\hline Total All Jobs & 169,815 & $100.0 \%$ & 173,988 & $100.0 \%$ \\
\hline
\end{tabular}

Source: US Census Bureau, LED OnTheMap Origin-Destination Database

(Beginning of Quarter Employment, 2nd Quarter 2008, 2007, 2006, 2005, 2004, 2003, and 2002)

Table 3-6: Jobs in Places (Cities, CDPS, etc.) Where Workers are Employed

\begin{tabular}{|c|c|c|c|c|}
\hline \multicolumn{5}{|c|}{ Jobs in Places (Cities, CDPs, etc.) Where Workers Live } \\
\hline & \multicolumn{2}{|c|}{2007} & \multicolumn{2}{|c|}{2002} \\
\hline & Count & Share & Count & Share \\
\hline Oakland city, CA & 42,668 & $25.1 \%$ & 49,913 & $28.7 \%$ \\
\hline San Francisco city, CA & 12,817 & $7.5 \%$ & 11,021 & $6.3 \%$ \\
\hline San Leandro city, CA & 6,535 & $3.8 \%$ & 6,959 & $4.0 \%$ \\
\hline Alameda city, CA & 5,569 & $3.3 \%$ & 7,208 & $4.1 \%$ \\
\hline Hayward city, CA & 5,187 & $3.1 \%$ & 5,506 & $3.2 \%$ \\
\hline Berkeley city, CA & 4,944 & $2.9 \%$ & 6,232 & $3.6 \%$ \\
\hline Richmond city, CA & 3,735 & $2.2 \%$ & 4,521 & $2.6 \%$ \\
\hline San Jose city, CA & 3,722 & $2.2 \%$ & 3,103 & $1.8 \%$ \\
\hline Castro Valley CDP, CA & 3,362 & $2.0 \%$ & 3,567 & $2.1 \%$ \\
\hline Concord city, CA & 2,942 & $1.7 \%$ & 3,257 & $1.9 \%$ \\
\hline All Other Locations & 78,334 & $46.1 \%$ & 72,701 & $41.8 \%$ \\
\hline
\end{tabular}

Source: US Census Bureau, LED OnTheMap Origin-Destination Database

(Beginning of Quarter Employment, 2nd Quarter 2008, 2007, 2006, 2005, 2004, 2003, and 2002)

Table 3-7: Oakland Labor Force Estimates for 2020

\begin{tabular}{|l|l|l|l|l|l|l|l|}
\hline $\begin{array}{l}\text { Total } \\
\text { Employed } \\
(2000)\end{array}$ & $\begin{array}{l}\text { Total } \\
\text { Labor } \\
\text { Force } \\
(2000)\end{array}$ & $\begin{array}{l}\text { Labor Force } \\
\text { Participation } \\
\text { Rate }\end{array}$ & $\begin{array}{l}\text { Current(2007) } \\
\text { Number of } \\
\text { Oakland } \\
\text { Resident } \\
\text { Employees }\end{array}$ & $\begin{array}{l}\text { \% of } \\
\text { Participants } \\
\text { Living in } \\
\text { Oakland }\end{array}$ & $\begin{array}{l}\text { Estimated } \\
2020 \\
\text { Labor } \\
\text { Force }\end{array}$ & $\begin{array}{l}2020 \\
\text { Participation } \\
\text { Estimate }\end{array}$ & $\begin{array}{l}\text { Estimate of } \\
\text { Participants } \\
\text { in Oakland }\end{array}$ \\
\hline 174,743 & 190,725 & $91.62 \%$ & 42,668 & $24 \%$ & 340,489 & 311,956 & 74,780 \\
\hline
\end{tabular}




\section{Chapter 4: Job Opportunities for Career Ladders}

\section{Introduction}

Certain job trends provide opportunities for creating career ladders. Trends in employment and job openings in certain industries help to create strategic career ladders that will be most useful to individuals and firms by taking advantage of anticipated skills and honing those skills in career ladder participants. The following sections highlight three industries that may benefit from strategic career ladders that provide skills that cater to those demands.

\section{Emerging Trends in Industries}

Table 4-1 shows career ladder potential for the health care industry, the highest employer of Oakland residents. The table shows the average annual wage for each entry-level occupation, as well as the projected number of jobs in that occupation. In addition to the education requirements for these entrylevel jobs, possible choices for career advancement are listed.

One of the top emerging industries identified by the California Employment Development Department (CA EDD) is health care and social assistance. As a whole, the industry is projected to employ an additional 14,100 jobs by 2016 , most of which are listed above and require relatively little training to acquire. Nursing aides, orderlies, and attendants jobs require successful completion of a stateapproved Nursing Assistant program and the state nursing certification and competency exam. The skills and experience gained as a nursing aide, orderly, or attendant can provide a solid foundation to become a home health aide, medical assistant, licensed vocational nurse, rental clerk medical equipment and supplies, or phlebotomist. 
Table 4-1: Health Care and Social Assistance

\begin{tabular}{|c|c|c|c|}
\hline $\begin{array}{l}\text { Occupation } \\
\text { (Average } \\
\text { Annual Wage) }\end{array}$ & $\begin{array}{l}\text { Projected } \\
\text { Job/Employment Growth } \\
\text { in Alameda County } \\
(2006-2016)\end{array}$ & $\begin{array}{l}\text { Education/ } \\
\text { Training } \\
\text { Required }\end{array}$ & Possible Career Paths \\
\hline $\begin{array}{l}\text { Nursing Aides, } \\
\text { Orderlies, } \\
\text { Attendants } \\
(\$ 27,124)\end{array}$ & 1,830 new jobs & $\begin{array}{l}\text { Short Term (ST) } \\
\text { On-The-Job } \\
\text { (OJT) Training }\end{array}$ & $\begin{array}{l}\text { Home Health Aide; Medical } \\
\text { Assistant; Licensed Vocational } \\
\text { Nurse; Rental Clerk Medical } \\
\text { Equipment and Supplies; } \\
\text { Phlebotomist }\end{array}$ \\
\hline $\begin{array}{l}\text { Home Health } \\
\text { Aides }(\$ 22,164)\end{array}$ & 1,734 New Jobs & ST OTJ Training & $\begin{array}{l}\text { Physical Therapy Aide; Medical } \\
\text { Assistant; Registered Nurse; } \\
\text { Licensed Vocational Nurse; } \\
\text { Certified Nursing Assistant }\end{array}$ \\
\hline $\begin{array}{l}\text { Medical Assistants } \\
(\$ 31,96)\end{array}$ & $\begin{array}{l}18 \% \text { Increase in } \\
\text { Employment ( } 809 \text { New } \\
\text { Jobs) }\end{array}$ & ST OJT Training & $\begin{array}{l}\text { Medical Coder; Medical Assisting } \\
\text { Instructor; Medical and Clinical } \\
\text { Laboratory Technician; Licensed } \\
\text { Vocational Nurse }\end{array}$ \\
\hline $\begin{array}{l}\text { Pharmacy } \\
\text { Technicians } \\
(\$ 36,353)\end{array}$ & $\begin{array}{l}34.6 \% \text { Increase in } \\
\text { Employment (644 New } \\
\text { Jobs) }\end{array}$ & $\begin{array}{l}\text { Moderate }(\mathrm{M}) \\
\text { OJT Training }\end{array}$ & $\begin{array}{l}\text { Medical Equipment Preparer; } \\
\text { Occupational Therapy Assistant; } \\
\text { Dietician and Nutritionist; Dietetic } \\
\text { Technician }\end{array}$ \\
\hline $\begin{array}{l}\text { Social and Human } \\
\text { Service Assistants } \\
(\$ 33,441)\end{array}$ & $\begin{array}{l}20.1 \% \text { Increase in } \\
\text { Employment (679 New } \\
\text { Jobs) }\end{array}$ & M OJT Training & $\begin{array}{l}\text { Occupational Therapist Assistant; } \\
\text { Psychiatric Technician; Social } \\
\text { Worker }\end{array}$ \\
\hline $\begin{array}{l}\text { Respiratory } \\
\text { Therapists } \\
(\$ 63,684) \\
\end{array}$ & $\begin{array}{l}19.7 \% \text { Increase in } \\
\text { Employment (153 New } \\
\text { Jobs) }\end{array}$ & Associate Degree & $\begin{array}{l}\text { Medical and Clinical Laboratory } \\
\text { Technologist; Respiratory } \\
\text { Therapist Instructor }\end{array}$ \\
\hline $\begin{array}{l}\text { Registered Nurses } \\
(\$ 80,551)\end{array}$ & $\begin{array}{l}17.7 \% \text { Increase in } \\
\text { Employment }(3,624 \mathrm{New} \\
\text { Jobs })\end{array}$ & Associate Degree & $\begin{array}{l}\text { Nurse Practitioner; } \\
\text { Certified Registered Nurse } \\
\text { Anesthetist; Certified Physician } \\
\text { Assistant; Nursing Administrator; } \\
\text { Nursing, Clinical Specialty }\end{array}$ \\
\hline Total & 9,473 New Jobs & - & - \\
\hline
\end{tabular}

Home health aides require state certification and can advance to physical therapy aide, medical assistant, registered nurse, licensed vocational nurse, certified nursing assistant. Medical assistants require training and would benefit great from certification by the American Association of Medical Assistants (AAMA). Possible career advancement options include medical coder, medical assisting instructor, medical and clinical laboratory technician, licensed vocational nurse. Employment as a pharmacy technician requires completion of a state board approved Pharmacy Technician training program. Experience as a pharmacy technician can help an individual in becoming a medical equipment preparer, 
occupational therapy assistant, dietician and nutritionist and dietetic technician. There are no listed certification requirements for the social and human service assistance occupation, most likely because the occupation includes many different types of assistance positions. Possible career paths for social and human service assistants include occupational therapist assistant, psychiatric technician, and social worker.

Respiratory therapists require more training and certification than the other occupations listed. Consequently, respiratory therapists earn significantly higher wages than the other occupations. The requirements of this job include completion of state approved respiratory therapy program as well as licensure and completion of relevant continuing education every two years. Possible career paths include medical and clinical laboratory technologist, respiratory therapist instructor, and supervising respiratory therapist.

Finally, registered nurses make up the majority of those employed in health care and social assistance. Registered nurses have completed a state board approved nursing program and have passed the State Board of Registered Nursing exam to obtain licensure. These more significant requirements also earn Registered Nurses higher wages than most other health care and social assistance occupations. Registered nurses have the potential to advance to a nurse practitioner, certified registered nurse anesthetist, certified physician assistant, nursing administrator, or nursing with a clinical specialty.

Table 4-2 shows employment growth and statistics for the education services industry. Entrylevel jobs in this industry require higher levels of education, but also pay higher wages. There will be an estimated 12,000 new jobs in these entry-level education services occupations in Alameda County. Because education services encompass a wide variety of occupations, it is difficult to map out possible career paths for entry-level jobs in this industry. 
Table 4-2: Education Services

\begin{tabular}{|l|l|l|}
\hline $\begin{array}{l}\text { Occupation and (Median } \\
\text { Annual Wage) }\end{array}$ & $\begin{array}{l}\text { Projected Job/Employment } \\
\text { Growth }(\mathbf{2 0 0 6}-2016)\end{array}$ & $\begin{array}{l}\text { Education/ Training } \\
\text { Required }\end{array}$ \\
\hline Teacher Assistants $(\$ 30,733)$ & 2,630 New Jobs & ST OJT Training \\
\hline $\begin{array}{l}\text { Graduate Teaching Assistants } \\
(\$ 27,062)\end{array}$ & $\begin{array}{l}20.4 \% \text { Increase in Employment } \\
(907 \text { New Jobs) }\end{array}$ & Bachelor's Degree \\
\hline $\begin{array}{l}\text { Vocational Education Teachers, } \\
\text { Postsecondary }(\$ 65,210)\end{array}$ & $\begin{array}{l}18.9 \% \text { Increase in Employment } \\
(251 \text { New Jobs) }\end{array}$ & $\begin{array}{l}\text { Post-Secondary Vocational } \\
\text { Education }\end{array}$ \\
\hline $\begin{array}{l}\text { Elementary School Teachers, } \\
\text { Except Special Education } \\
(\$ 59,939)\end{array}$ & B,690 New Jobs & Bachelor's Degree \\
\hline $\begin{array}{l}\text { Secondary School Teachers, } \\
\text { Except Special and Vocational } \\
\text { Education (\$61,887) }\end{array}$ & 3,570 New Jobs & Bachelor's Degree \\
\hline Total & & \\
\hline Source: (California Employment Development Department, 2010) & - \\
\hline
\end{tabular}

Table 4-3: Logistics

\begin{tabular}{|l|l|l|}
\hline $\begin{array}{l}\text { Occupation (Median Annual } \\
\text { Wage) }\end{array}$ & $\begin{array}{l}\text { Projected Job/Employment } \\
\text { Growth (2006-2016) }\end{array}$ & Education/Training Required \\
\hline $\begin{array}{l}\text { Cleaners of Vehicles \& } \\
\text { Equipment (\$19,008) }\end{array}$ & 780 New Jobs & ST OTJ Training \\
\hline $\begin{array}{l}\text { Laborers and Freight, Stock and } \\
\text { Material Movers, Hand } \\
\$ 25,515)\end{array}$ & 5,000 New Jobs & ST OTJ Training \\
\hline $\begin{array}{l}\text { Truck Drivers, Heavy and } \\
\text { Tractor-Trailer }(\$ 42,825)\end{array}$ & 2,420 New Jobs \\
\hline $\begin{array}{l}\text { Customer Services } \\
\text { Representatives }(\$ 37,521)\end{array}$ & 6,380 New Jobs & ST OTJ Training \\
\hline $\begin{array}{l}\text { Shipping, Receiving, and Traffic } \\
\text { Clerks }(\$ 31,932)\end{array}$ & 1,750 New Jobs & Moderate OTJ Training \\
\hline $\begin{array}{l}\text { Sales Representatives, } \\
\text { Wholesale \& Manufacturing, } \\
\text { except Technical \& Scientific } \\
\text { Products (\$59,252) }\end{array}$ & 2,770 New Jobs & Moderate OTJ Training \\
\hline Total & & \\
\hline Source: (California Employment Development Department, 2010) & \\
\hline
\end{tabular}

On the whole, there will be approximately 19,100 new logistics jobs in Alameda County that require very little training, as shown above. Career advancement in the logistics industry mainly results from earning certification in a specialized skill, such as forklift operation or preventative maintenance and inspection. One way that those seeking career advancement in logistics is through the Alameda 
Transportation and Logistics Academic Support (ATLAS) program offered through the College of Alameda.

\section{Educational Attainment and Employment Potential}

Table 4-4 shows income potential by educational attainment. According to the groups of education levels discussed earlier, the most job openings are at the level with the least educational requirement. That is, those who are still earning below $\$ 30,000$ per year but could be increasing what they currently earn.

Table 4-4: Income Potential by Educational Attainment

\begin{tabular}{|c|c|c|}
\hline Education Level & $\begin{array}{l}\text { Number of Job } \\
\text { Openings }\end{array}$ & Median Annual Wage Range \\
\hline 1-5 Graduate \& Professional & 24,380 & $\$ 61,887-\$ 112,497$ \\
\hline 6 - Associate Degree & 7,390 & $\$ 53,089-\$ 93,646$ \\
\hline 7 - 11 Below Assoc. but Earning more than $\$ 30 \mathrm{~K} /$ year & 43,740 & $\$ 30,733-\$ 64,973$ \\
\hline $\begin{array}{l}7 \text { - } 11 \text { Below Assoc., Earning below } \$ 30 \mathrm{~K} / \text { year but } \\
\text { increase }\end{array}$ & 105,670 & $\$ 17,420-\$ 29,745$ \\
\hline
\end{tabular}

Source:BLS 2006-2016 Occupations with the Most Job Openings, Oakland-Fremont-Hayward Division (Alameda and Contra Costa Counties)

Table 4-5 matches employment growth potential with the educational attainment groups discussed earlier. Those individuals in each range can see the number of job openings suited to them and may decide to make an investment in their education or vocational training. For example, those with an Associate Degree may decide that there are not enough job openings for them and that an investment in education would help increase their wages and standard of living. Unfortunately, those individuals may also take a low-paying job with little to no potential and suffer through the lack of support in the current economy. 
Table 4-5: Potential Employment Growth by Educational Attainment Groups

\begin{tabular}{|l|c|c|c|c|c|c|}
\hline & \multicolumn{3}{|c|}{ Total Jobs } & \multicolumn{3}{c|}{ Fastest Growing Jobs } \\
\hline Education Level & $\mathbf{2 0 0 6}$ & $\mathbf{2 0 1 6}$ & $\begin{array}{l}\text { Percent } \\
\text { Change }\end{array}$ & $\mathbf{2 0 0 6}$ & $\begin{array}{c}\mathbf{2 0 1 6} \\
\text { Percent } \\
\text { Change }\end{array}$ \\
\hline 1-5 Graduate \& Professional & 287,480 & 314,250 & $9 \%$ & 36,030 & 45,690 & $27 \%$ \\
\hline 6 - Associate Degree & 44,650 & 50,930 & $14 \%$ & 20,550 & 24,790 & $21 \%$ \\
\hline $\begin{array}{l}\text { Earning more than } \\
\text { \$30K/year }\end{array}$ & 471,240 & 492,030 & $4 \%$ & 13,290 & 16,220 & $22 \%$ \\
\hline $\begin{array}{l}7 \text { - 11 Below Assoc., } \\
\text { Earning below \$30K/year } \\
\text { but increase }\end{array}$ & 333,540 & 363,190 & $9 \%$ & 41,460 & 56,040 & $35 \%$ \\
\hline
\end{tabular}

Source: BLS 2006-2016 Fastest Growing Occupations, Oakland-Fremont-Hayward Division (Alameda and Contra Costa Counties) 


\section{Chapter 5: Conclusions and Recommendations}

There are many different theories of why poverty exists. Some believe that the problem is based on individual deficiency, while others believe the problem is systemic and rooted in discrimination. There are also theories that combine these two reasons. Though it is difficult to place blame on just one facet of the economy, there are several strategies for workforce development that speak to different causes.

In Oakland, there is a significant need for workforce development. There are strong correlations there between income, educational attainment, and wages earned. The population is geographically separated by income class. On the West side reside people with lower educational attainment and lower paying jobs. People earning higher wages on the East side of the City also exhibit higher levels of educational attainment.

Approximately one third of all jobs in Oakland pay wages that give their employees low-income status. It is this group of employees—resident workers - that can benefit most from the findings of this study. Today, Oakland has a pool of 42,000 resident employees who could potentially benefit from the career ladders identified in this study. By 2020, the pool of potential beneficiaries could grow to 75,000 resident employees. While those in the low-income category can benefit the most from the identification and creation of career ladders, any resident in the labor force can benefit from a job training program. The industries identified for career ladder investment are healthcare, education services and logistics, which are emerging not only in Oakland but nationwide. The healthcare industry is the largest employer in Oakland and may add over 9,400 jobs over a ten-year span, while education services and logistics may provide 19,100 and 12,000 new jobs, respectively. This study recommends that training facilities focus workforce development that is targeted at these industries. For example, community colleges can bolster their education programs that focus on one or more of the identified industries and focus on aiding the completion of short term on-the-job training. They could then offer programs that increase competency in a given field of study as well as career development aides such as interview and job search skills. 


\section{References}

Alliance of Sector Skills Councils. (2010). Alliance of Sector Skills Councils Manifesto 2010.

Bradshaw, T. (2005). Theories of Poverty and Anti-Poverty Programs. Davis, CA: Univeristy of Calfornia, Davis.

Iceland, J. (2006). Poverty in America: A Handbook. Berkeley: University of California Press.

Lewis, O. (1966). La Vida. New York: Random House.

Merrefield, C. (2009, January 13). Emerging Industries: Stimulus 2.0. Retrieved May 15, 2010, from Crain's New York: http://futurenyc.crainsnewyork.com/2009/01/13/emerging-industries-stimulus-20/

Newman, K. S. (1999). No Shame in My Game: The Working Poor in the Inner City. New York: Russell Sage Foundation.

Schiller, B. R. (1989). The Economics of Poverty and Discrimination. Englewood Cliffs, NJ: Prentice Hall.

The Board of Governors of the California Community Colleges. (2001). Ladders of Opportunity: A Board of Governors' Initiative for Developing California's New Workforce. Sacramento: California Community Colleges System.

Valentine, C. A. (1968). Culture and Poverty. Chicago: University of Chicago Press.

Weber, M. (2001). Protestant Ethic and the Spirit of Capitalism. New York: Routelege.

Wilson, P. (1995). One Stop Career Center. Los Angeles: Patricia Wilson Design. 